\title{
Cytotoxic and Antimicrobial Efficacy of Silver Nanoparticles Synthesized Using a Traditional Phytoproduct, Asafoetida Gum [Corrigendum]
}

Devanesan S, Ponmurugan K, AlSalhi MS, Al-Dhabi NA. Int J Nanomedicine. 2020;15:4351-4362.

The authors have advised there is an error in Figure 1 on page 4354 . Due to an error at the time of figure assembly
Figure 2 was included as Figure 1C. The correct Figure 1 is shown below.

The authors apologize for this error.
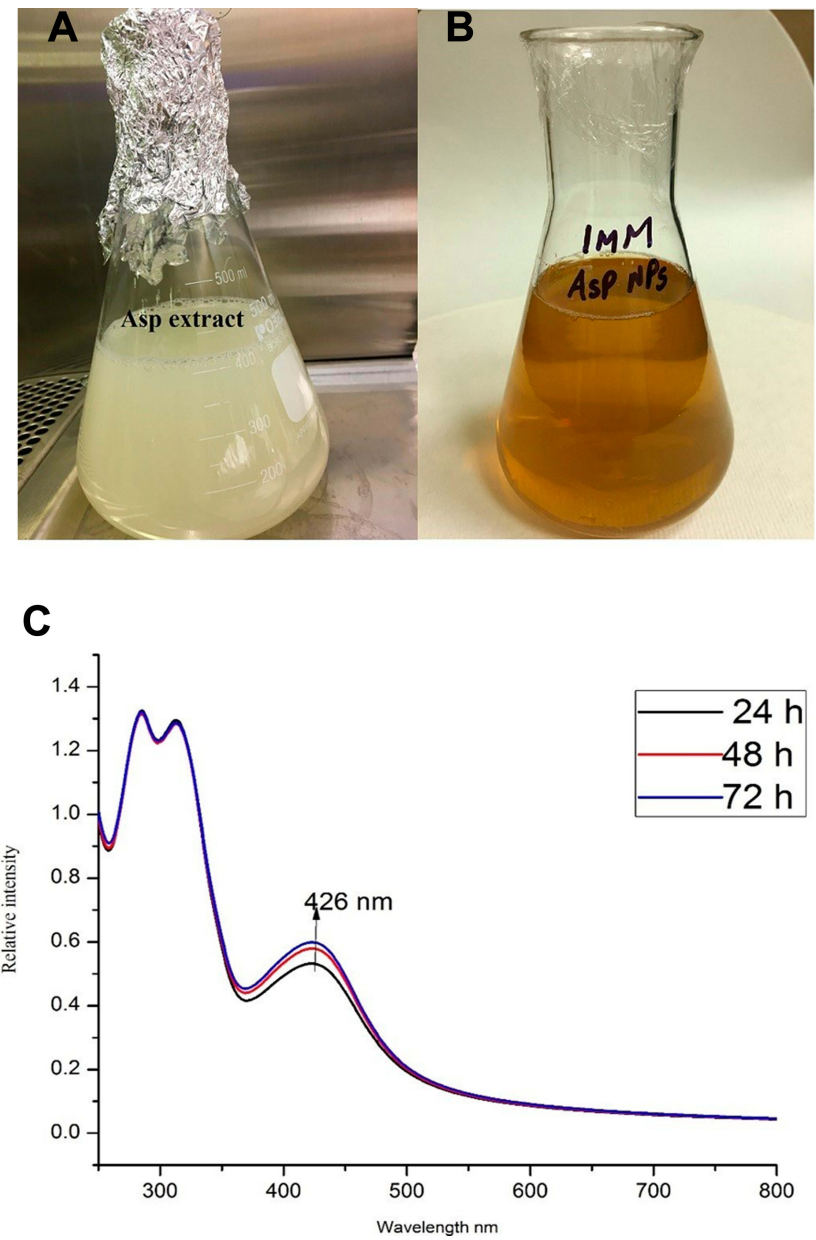

Figure I Asafoetida gum extracts, (A) representative before formation nanoparticles asafoetida gum extracts (B) silver nanoparticles formed after reaction of asafoetida gum extracts with I mM of silver nitrate (C) UV-Vis spectrum of As-AgNPs at $426 \mathrm{~nm}$ with different time intervals (24-72 h). 


\section{Publish your work in this journal}

The International Journal of Nanomedicine is an international, peerreviewed journal focusing on the application of nanotechnology in diagnostics, therapeutics, and drug delivery systems throughout the biomedical field. This journal is indexed on PubMed Central, MedLine, CAS, SciSearch ${ }^{\circledR}$, Current Contents ${ }^{\circledR} /$ Clinical Medicine,
Journal Citation Reports/Science Edition, EMBase, Scopus and the Elsevier Bibliographic databases. The manuscript management system is completely online and includes a very quick and fair peer-review system, which is all easy to use. Visit http://www.dovepress.com/ testimonials.php to read real quotes from published authors. 